\title{
Plant species identity and richness influence microbial respiration of soil microorganisms on various functional groups in northeastern Patagonia, Argentina
}

\begin{abstract}
Studies on basal soil respiration (i.e., under undisturbed conditions) are very important because they can be used as indirect indicators of the biological activity in those soils; this ecological process is recognized as the major source of carbon flux from the soil surface, and one of the crucial components of the carbon cycle in terrestrial ecosystems. The objectives of this study were to determine the microbial respiration of soil microorganisms at various levels of plant species richness and developmental morphology stages in various perennial grass (Nassella longiglumis, N. tenuis, Amelichloa ambigua), and herbaceous (Atriplex semibaccata) and woody (Larrea divaricata, Schinus fasciculatus) dicots grown in experimental plots during 2013 and 2014. There were 54 experimental plots. On each of 6 blocks, there was a plot $(1.25 \times 1.25 \mathrm{~m})$ for each of the 6 species (monocultures) and one plot each having combinations of 2, 4 or 6 species. Six hundred and twenty nine plants were reserved to replace dead plants in the plots $[629+1944$ plants from the plots (54 plots x 36 plants per plot $)=2573$ plants in total] . An auger $(3 \mathrm{~cm}$ diameter, $20 \mathrm{~cm}$ length $)$, was used to obtain six replicate root + soil samples at each of four sampling times during those years. Basal soil respiration was similar $(p>0.05)$ or greater $(p<0.05)$, but ever lower, as plant species richness increased. Our results demonstrated that the plant species differences in microbial respiration in the experimental plots were species richness-, developmental morphology stage-, and sampling-time dependents.
\end{abstract}

Volume 2 Issue 2 - 2018

\author{
Cardillo DS,' Busso CA, 1,2 Ambrosino ML, 1,3 \\ Torres YA, ${ }^{2,4}$ Ithurrart LS, ,,2 Palomo R \\ 'Consejo Nacional de Investigaciones Científicas y Técnicas de \\ la República Argentina (CONICET), Argentina \\ ${ }^{2}$ Departamento de Agronomía, Universidad Nacional del Sur \\ (UNS), Argentina \\ ${ }^{3}$ Facultad de Ciencias Exactas y Naturales, Universidad Nacional \\ de La Pampa,Argentina \\ ${ }^{4}$ Comisión de Investigaciones Científicas de la Provincia de \\ Buenos Aires (ClC), Argentina
}

\begin{abstract}
Correspondence: Carlos Busso,Agonomy Department National Council for Scientific and Technological Research of Argentina, San Andrés, 8000 Bahía Blanca, Pcia. Buenos Aires, Argentina,Email cebusso@criba.edu.ar, carlosbussol@gmail.com
\end{abstract}

Received: January II, 2018 | Published: March 20, 2018

Keywords: microbial respiration, grasses, herbaceous dicots, shrubs, Argentina

\section{Nomenclature}

http://www.floraargentina.edu.ar/detalleespecie. asp? forma $=\&$ variedad $=\&$ subespecie $=\&$ especie $=$ tenuis $\&$ espcod $=23447 \&$ genero $=$ Nassella\&autor $=8086 \&$ deDonde $=4$

\section{Abbreviations: $\mathrm{C}$, carbon; $\mathrm{N}$, nitrogen}

\section{Introduction}

Microbiological activity is a general term which includes all metabolic reactions and interactions of the soil microflora and macrofauna. ${ }^{1}$ Soil microorganisms contribute to soil fertility and aggregate formation in degraded soils. ${ }^{2}$ However, it is only during the last decades that ecologists have beginning to explore the underground communities and their functional significance for the plant communities and ecosistemic processes. ${ }^{3,4}$ Exudates from plant roots and decomposition of the underground litter affect the associated roots and the communities of the underground decomposers, which in time regulate soil nutrient availability and plant growth.

Ecosystem functioning is regulated by the interactions of the organisms which are part of it. ${ }^{6}$ The interactions between the aboveand below-ground biotas, throughout plant-mediated mechanisms, are potentially very important in determining community structure, and work like those that exist between spatially coexistent species. ${ }^{7}$ The establishment of new plant species in the soil might determine the composition of the sub-community by influencing the associated roots and the decomposer microorganisms. These in turn regulate nutrient availability and plant growth. ${ }^{8}$

Wardle et al. ${ }^{9}$ showed that microbial diversity responds much more rapidly than other measurements to manipulations of plant community structure. Loranger-Merciri et al. ${ }^{10}$ \& Wang et al. ${ }^{11}$ concluded that a mixture of plant species improves the community of soil bacteria. Results of Loranger-Merciri et al. ${ }^{10}$ also emphasized the rapid responses of the activity and diversity of bacterial communities to the loss of plant species richness. This makes soil microorganisms a sensitive group to measurements when effects of plant species richness are studied on soil microbial communities in rangeland ecosystems. The effects of plant species richness are still scarce on other important ecosystem processes. For example, their effects on soil respiration have been little investigated, and contradictory results have been obtained. ${ }^{12}$ De Boeck et al. ${ }^{13}$ did not find any relationship between plant diversity and soil respiration. Also, soil respiration has been rarely studied, often in short-term studies ${ }^{13}$. This has determined that soil respiration at different developmental morphology stages could not be determined within the same plant species.

Soil respiration is an important part of the global carbon cycle. It includes root respiration and the heterotrophic activity of the soil $\mathrm{C}$ recycling coming from litter, roots and their exudates. ${ }^{14}$ Therefore, changes in the factors that control soil respiration rates can have an important impact in the atmospheric $\mathrm{CO}_{2}$ concentration. ${ }^{12}$ Several studies using rangeland species have shown that the more diverse communities tend to be more productive. ${ }^{15}$ This is conducive to an 
increasing entrance of $\mathrm{C}$ in the soil. However, more diverse plant communities have also shown an increased efficiency in $\mathrm{N}$ use (i.e., $\mathrm{N}$ concentration decreased in the produced biomass). ${ }^{16}$ This reduction in $\mathrm{N}$ concentration in the organic matter might negatively affect both autotrophic and heterotrophic components of soil respiration.

Regarding the influence of species identity in soil microbiology, it is well knew that particular species can modify the activity and size of soil microbial populations. When this happens, those species have the potential to affect key ecosystem processes like soil respiration. ${ }^{17}$ This is because of the close, positive relationship that exists between soil respiration and the biomass of soil microorganisms. ${ }^{18}$ Nevertheless, it is unknown the relative importance of the plant community species richness on the regulation of soil respiration rates. ${ }^{17}$ Understanding of these relationships is important because species extinction rates are increasing, and several of the legislation objectives for conservation are based on restoring or maintaining plant species richness. ${ }^{15}$

Human activities have contributed to soil degradation, ${ }^{19}$ which can produce great changes on its biological properties..$^{20}$ Such degradation can diminish soil microbial biomass, and the underground microbial activity as a result. ${ }^{21}$ However, land restoration can promote increases in microbial biomass either in the short- or long-term. ${ }^{21}$ Loss of plant species richness can also modify rates of nutrient both cycling and decomposition. ${ }^{22}$ Nonetheless, few studies have examined the impact of a decreased plant species richness on the under-ground biota. ${ }^{8}$ Soil microorganisms are of great importance for long-term sustainability of ecosystems. ${ }^{23}$ This is because they play a key role in organic matter decomposition, nutrient cycling, maintenance of soil structure, and degradation of agrochemical contaminants. Soil microorganisms are mostly heterotrophs. Because of this, they utilize plant either exudates or materials as foods. A reduction in food quality and quantity, as a result of a loss in plant species richness, can modify the abundance of soil microbial communities. ${ }^{24,25}$

Soil respiration is an important indicator of its biological activity. ${ }^{26}$ Soil respiration and the atmospheric concentration of $\mathrm{CO}_{2}$ highly depend on the photosynthetic plant activity that provides carbohydrates from leaves to roots and the rhizosphere. ${ }^{27}$ As a result, the variation between ecosystems (e.g., on leaf phenology, plant growth, photosynthetic rates) is likely to influence under-ground $\mathrm{C}$ dynamics. ${ }^{28}$ However, few studies have addressed how differences in plant phenology might affect soil microbial respiration. The origin of root respiration, as a component of total soil respiration, is leaf photosynthesis. As a result, soil respiration could depend on leaf emergence and leaf area expansion. ${ }^{29}$

Our objective was to evaluate the impact of the identity, species richness, and the developmental morphology stage of the study species on the soil microbial activity. With this purpose, basal soil respiration was determined on experimental plots at the field that contained different combinations of plant species. Working hypotheses were that soil basal respiration is greater (1) at greater than lower species richness, and (2) at the reproductive than vegetative stage of developmental morphology.

\section{Materials and methods}

\section{Study site}

This study was conducted in the Chacra Experimental Patagones, southwest of the Province of Buenos Aires (40 39' 49.7' S, 62 $53^{\circ}$ ' 6.4" W; $40 \mathrm{~m}$ a.s.1), within the Phytogeographical Province of the Monte $^{30}$ during 2013 and 2014. Determinations were made within a 7-year-exclosure to domestic livestock of 0.025 ha.

\section{Climate}

It is temperate semi-arid, with precipitations concentrated in summer and autumn. Annual mean precipitation was $421 \mathrm{~mm}$ during 1981-2012, with minimum and maximum values of 196mm (2009) and $877 \mathrm{~mm}$ (1984), respectively. ${ }^{31}$ Precipitation, evapotranspiration, air and soil temperatures, wind speed and relative humidity (Figure 1) were determined by an automatic meteorological station located a few meters away from the experimental plots (Figure 2). Total annual precipitation was $513 \mathrm{~mm}$ during 2012, 422 $\mathrm{mm}$ during 2013, and 597mm during 2014.

\section{Soil}

Landscape on the region is mostly a plain, although there are waves and isolated micro-depressions. The original materials of the predominant soils are fine sands, which are transported by wind and deposited on tosca, and older, weakly consolidated silty-sandy materials. ${ }^{32}$ Soil was classified as a typical Haplocalcid (Nilda Mabel Amiotti, Dpto. de Agronomía UNSur, Bahía Blanca, Argentina, personal communication). Mean $\mathrm{pH}$ is 7 and there are no limitations of depth in the soil profile.

\section{Vegetation}

The plant community is an open shrubby stratum that includes herbaceous species of different quality for livestock production. ${ }^{33}$ Nassella longiglumis (Phil.) Barkworth (a late-seral species: Distel \& Bóo $^{34}$ ), Nassella tenuis (Phil.) Barkworth (an intermediate-seral species: Saint Pierre et al. ${ }^{35}$ ), and Pappostipa speciosa and Amelichloa ambigua (Speg.) Arriaga \& Barkworth (earlier seral species: Saint Pierre et al. ${ }^{35}$ ) are $\mathrm{C}_{3}$ native perennial grasses in the Phytogeographical Province of the Monte, Argentina. This Province includes approximately 554, 138 ha in the Partido de Patagones, Province of Buenos Aires. Dominance of these species in the community depends, at least in part, of the grazing history, and frequency and intensity of fires. ${ }^{34}$ Characteristic rangeland management at the south of this region is continuous grazing with excessive stocking rate. ${ }^{36}$ Pappostipa speciosa and Amelichloa ambigua have a low preference by grazing animals ${ }^{37}$ while $N$. longiglumis and $N$. tenuis are highly preferred. As a result, $N$. longiglumis and $N$. tenuis might be highly selected by domestic herbivory at different times during their developmental morphology stages. The either low frequency or lack of fires combined with severe livestock overgrazing, diseminule availability of shrub species, and conditions which foster their seedling establishment have contributed to the (1) replacement of preferred by unpreferred perennial grasses, (2) establishment of annual species in the open, unvegetated areas during wet years, and (3) establishment of shrubby vegetation such as Condalia microphylla, Larrea divaricata Cav., and Schinus fasciculatus (Griseb.) I.M. Johnst., and the perennial forb Atriplex semibaccata R. Br. ${ }^{38}$ Study species [i.e., A. ambigua, $N$. longiglumis, N. tenuis (grasses); A. semibaccata (herbaceous perennial dicotyledonous); L. divaricata, S. fasciculatus (shrubs)] were included in this study because of they are abundant in rangelands of central Argentina. ${ }^{39}$ 

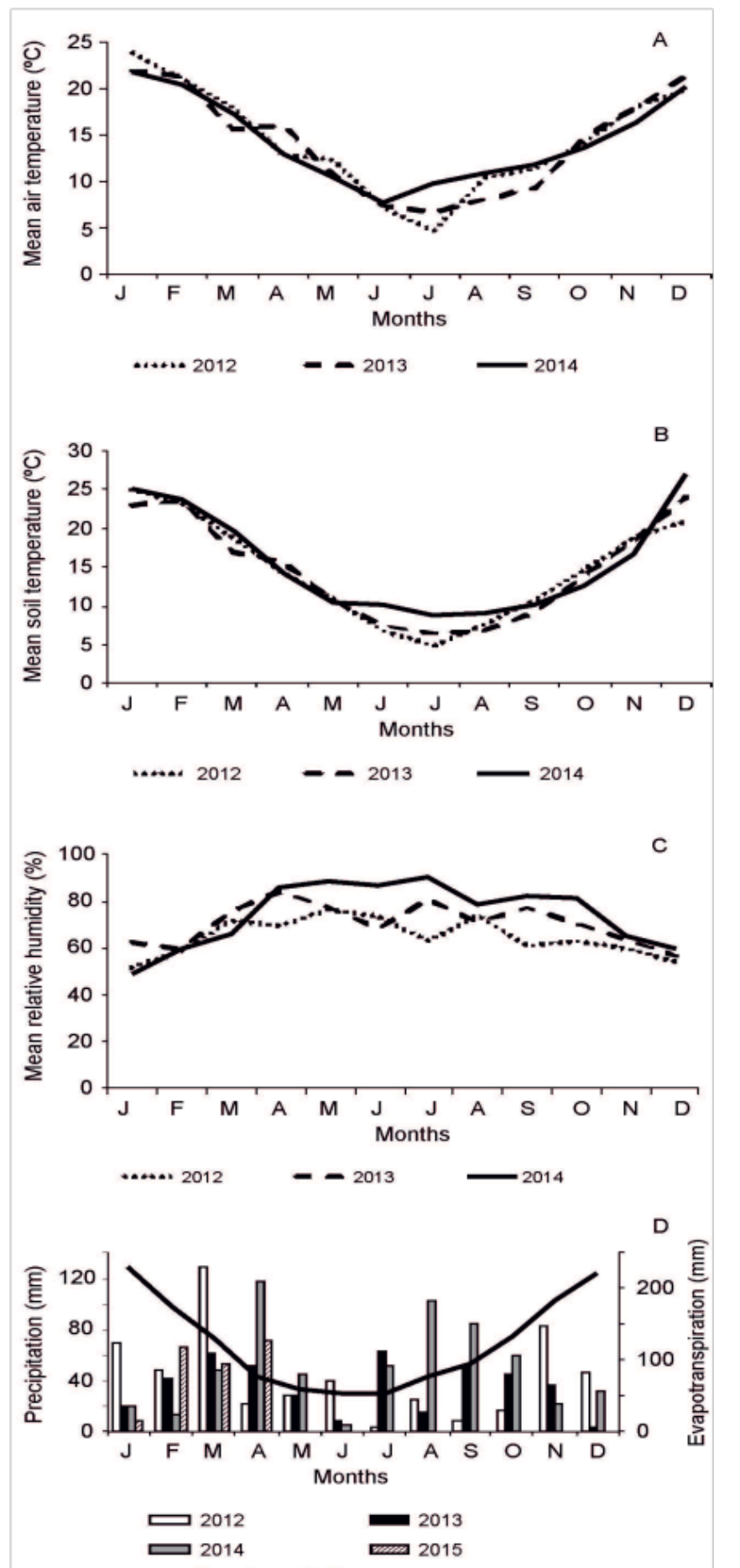

Figure I $(\mathbf{A}, \mathbf{B})$ Mean air and soil $\left(0-20 \mathrm{~cm}\right.$ depth) temperatures $\left({ }^{\circ} \mathrm{C}\right)$ (C) mean relative humidity (\%), (D) mean evapotranspiration and monthly precipitation during 2012 to 2015 .

\section{Transplanting of plants to the experimental plots}

The method to obtain plants of N. longiglumis, N. tenuis and A. ambigua was by cloning this tussock, perennial grasses. Transplanting of small individuals from the field to plastic pots was the method used to obtain plants of the shrubs L. divaricata and S. fasciculatus, and the forb A. semibaccata. Various studies were successful in obtaining plants of $A$. semibaccata via transplanting. ${ }^{40}$ Individuals of these species obtained via either cloning or transplanting were placed in 1.5 liter pots. These pots contained soil coming from the study field site, which was previously cleaned from residues using a 35-mesh screen. These pots were placed in a greenhouse and watered periodically. They were cleaned manually from emerging weeds. After a period of 6 months in the greenhouse, plants were allowed to acclimate to environmental conditions outside of it during 3 months before transplanting.
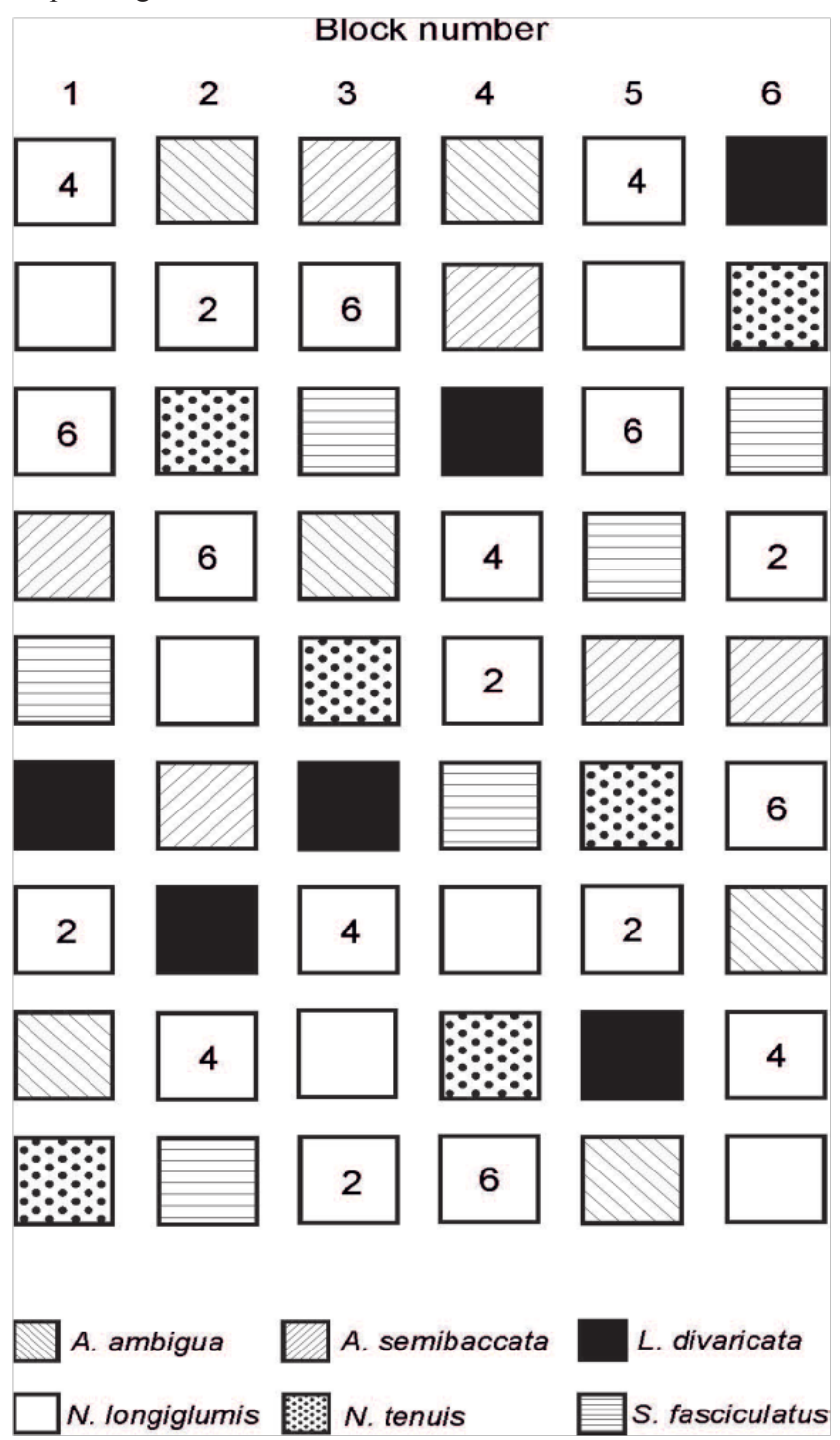

Figure 2 Diagram showing the distribution of the monocultures of each of the 6 species and the combination of 2, 4 and 6 species within each of the six experimental blocks. Distance among individual species was $0.25 \mathrm{~m}$ in horizontal and vertical lines.

At the beginning of October 2012 the soil in the 0.025 ha exclosure was prepared before transplanting. This was because it was compacted as a result of previous studies. ${ }^{41,42}$ With the purpose of having a loose soil, weed control and soil aeration, tillage was conducted twice. In 
addition, the soil was further cleaned twice with a rake, and also twice using a cultivator. Plant cover was controlled to a depth of $20 \mathrm{~cm}$ approximately. Afterwards, 36 experimental plots ( $1.25 \mathrm{x} 1.25 \mathrm{~m}$ each) were marked in the exclosure (Figure 2). During a month, 1944 plants were transplanted in that exclosure.

\section{Experimental design and measurements}

\section{Experimental plots}

Fifty four experimental plots were used in this study [4 treatments (monocultures of each of the 6 species, and combinations of 2, 4 and 6 plant species: Figure 2) x 6 replicates/treatment (i.e., 6 blocks, Figure 2)]. Each block contained monocultures of each of the study species (i.e., $N$. tenuis, $N$. longiglumis, A ambigua, A. semibaccata, $S$. fasciculatus and L. divaricata), and a plot with mixtures of $2(N$. tenuis and A. semibaccata; Figure 3), 4 (N. tenuis, A. semibaccata, $N$. longiglumis and S. fasciculatus; Figure 3) or 6 species (N. tenuis, $N$. longiglumis, A. ambigua, A. semibaccata, $S$. fasciculatus and $L$. divaricata; Figure 3) following a substitute design (i.e., plant density was equal in all study plots). The combination of species on each row of the 2, 4 or 6 species combination was at random (Figure 3). Six hundred and twenty nine plants were reserved to replace dead plants in the plots $(629+1944$ plants from the plots [54 plots x 36 plants per plot: Figure $2 \&$ Figure 3) $=2573$ plants in total].

Each experimental plot $(1.25 \times 1.25 \mathrm{~m})$ contained 36 plants, and each of its 6 rows (i.e., blocks) contained the 1 (i.e., monocultures), 2 , 4 , or 6 plant species combinations (Figure 3). Vertical and horizontal distances among plants within each plot was $0.25 \mathrm{~m}$ in all plant species combinations.

\section{Sampling procedure}

Plants located at the periphery of the experimental plots were not used for sampling. One plant of each species was selected per plot for soil + root sampling. This sampling was conducted underneath each species in all 4 species combinations of 1 (i.e. monocultures of each study species), 2, 4 or 6 species on each experimental plot. Each soil sample was taken diagonally to each plant using an auger $\left(62.83 \mathrm{~cm}^{3}\right.$ volume), from its periphery downward to the center of each plant, with an angle of approximately $30^{\circ}$ with respect to the soil surface. Sampling depth was 0-20 cm from the soil surface. The major part of the root biomass, and the root system dynamics in native perennial grasses occurs at that depth. ${ }^{43}$ Different plants of each species were sampled at each of the different sampling dates.

Samplings at the experimental plots were made on 12 May 2013 and 19 May 2014 (i.e., at the vegetative developmental morphology stage), and on 3 November 2013 and 5 November 2014 (i.e., at the reproductive developmental morphology stage). Since the marked plants were separated at least $25 \mathrm{~cm}$ from neighboring plants, and the sampling was made diagonally from the plant periphery towards the center of each plant, it was considered that most roots sampled with the auger came from the study plants. ${ }^{35}$ Afterwards, soil + root samples remained in a refrigerator to $4{ }^{\circ} \mathrm{C}$ previous to their analysis.

\section{Measurements}

Microbial respiration was measured using a soil microcosm after the static incubation and titration described by Zibilski. ${ }^{44}$ Three subsamples of $25 \mathrm{~g}$ each were used from each soil sample. These subsamples were placed in $200 \mathrm{ml}$ plastic pots. Soil was moistened with $3 \mathrm{ml}$ of distilled water free from carbon dioxide, and a histologic needle was used to make a homogeneous mixture. These flasks containing the soil + distilled, decarboxylated water were always maintained closed. Besides, $20 \mathrm{ml}$ of $\mathrm{NaOH}$ were placed in a $50 \mathrm{ml}$ vial. Four $\mathrm{ml}$ of distilled water free from $\mathrm{CO}_{2}$, and the flask with soil (now open) and the vial containing $\mathrm{NaOH}$ were placed within a widemouth glass flask. This was hermetically sealed with paraffined paper and it was maintained in darkness within a stove at $25^{\circ} \mathrm{C}$ during a week. A control was prepared for each sample set. This consisted in the big glass flask containing the $4 \mathrm{ml}$ of decarboxylated water and the vial with $\mathrm{NaOH}$, without including the flask with soil. The chemical reaction produced during the incubation period was $\mathrm{CO}_{2}+2 \mathrm{NaOH}$ $+\mathrm{Na}_{2} \mathrm{CO}_{3}+\mathrm{H}_{2} \mathrm{O}$. At the end of the incubation period, the flasks were taken out of the stove and they were prepared by its titration. To each vial, $2 \mathrm{ml}$ of $\mathrm{BaCl}_{2} 0,5 \mathrm{M}$ and a drop of phenolphthalein were added, and at the same time it was shaken while titulating with $\mathrm{HCl} 0.2 \mathrm{~N}$. Reactions that occurred during titration were:

$$
\begin{array}{cl}
\text { I. } & 2 \mathrm{NaOH}+\mathrm{Ba} \mathrm{Cl}_{2} \rightarrow 2 \mathrm{NaCl}+\mathrm{Ba}(\mathrm{OH})_{2} \\
\text { II. } & \mathrm{Na}_{2} \mathrm{CO}_{3}+\mathrm{BaCl}_{2} \rightarrow 2 \mathrm{NaCl}+\mathrm{BaCO}_{3} \\
\text { III. } & \mathrm{Ba}(\mathrm{OH})_{2}+2 \mathrm{HCl} \rightarrow \mathrm{BaCl}_{2}+2 \mathrm{H}_{2} \mathrm{O}
\end{array}
$$

When the dye changed color, the value $(\mathrm{ml}$ of $\mathrm{HCl})$ was taken for each sample. This was used to calculate the amount of $\mathrm{CO}_{2}$ per gr of soil using the following equation: (Control - Sample). 4.4/soil weight $=\mathrm{mg} \mathrm{CO} .7$ days $^{-1}$. gr soil ${ }^{-1}$

where Control: $\mathrm{ml}$ of $\mathrm{HCl}$ needed to tritrate the Control; Sample: $\mathrm{ml}$ of $\mathrm{HCl}$ needed to titrate the simple; 4,4 is a conversion factor between $\mathrm{HCl}$ and $\mathrm{CO}_{2}$; soil weight is the weight of the soil sample dried in an oven to $70^{\circ} \mathrm{C}$ during $48 \mathrm{hs}$.

\section{Statistical analysis}

Initially, a three-way-ANOVA was made on the plots, where the factors were the years, species and species richness. We compared first the plots with monocultures versus those where the 6 species were combined (i.e., 1 vs. 6). Because this comparison was significant, a priori contrasts were conducted among the factors. Whenever it was a two-way-interaction between any of the study factors, a two-wayANOVA was conducted to study the interaction. To study the effects of species richness for each of the study species separately, a block design with 2 factors [the treatments (fixed) and the developmental morphology stages (considered as random)] was utilized. The evaluated variable was the soil basal respiration. Treatments consisted of the number of species present on the experimental unit [combinations of 2 (N. tenuis, A. semibaccata), 4 (Schinus fasciculatus, Atriplex semibaccata, Nassella longiglumis, $N$. tenuis), or 6 species (Nassella longiglumis, Schinus fasciculatus, Nassella tenuis, Atriplex semibaccata, Amelichloa ambigua and Larrea divaricata) versus their respective monocultures. Each of the 54 plots (Figure 2) contained 36 plants (Figure 3). The number of blocks was 6 (Figure 2).

Since it was a mixed two-way-ANOVA(treatments $\mathrm{x}$ developmental morphology stages), the interaction was first tested. When it was significant $(\mathrm{p}<0.05)$, the mean square (MS) of the interaction was utilized as the MS of the error for treatment comparisons. It was not significant ( $>0.05)$, the residual MS was used as error. In all cases, the comparison among means was conducted by averaging the four sampling dates. Mean comparisons were made using the Dunnett's test. ${ }^{45}$ 


\section{COMBINATION OF TWO SPECIES}

\begin{tabular}{|c|c|c|c|c|c|}
\hline$N_{t}$ & $A_{s}$ & $N_{t}$ & $A_{s}$ & $N_{t}$ & $A_{s}$ \\
\hline$A_{s}$ & $N_{t}$ & $A_{s}$ & $N_{t}$ & $A_{s}$ & $N_{t}$ \\
\hline$N_{t}$ & $A_{s}$ & $N_{t}$ & $A_{s}$ & $N_{t}$ & $A_{s}$ \\
\hline$A_{s}$ & $N_{t}$ & $A_{s}$ & $N_{t}$ & $A_{s}$ & $N_{t}$ \\
\hline$N_{t}$ & $A_{s}$ & $N_{t}$ & $A_{s}$ & $N_{t}$ & $A_{s}$ \\
\hline$A_{s}$ & $N_{t}$ & $A_{s}$ & $N_{t}$ & $A_{s}$ & $N_{t}$ \\
\hline
\end{tabular}

\section{COMBINATION OF FOUR SPECIES}

\begin{tabular}{|l|l|l|l|l|l|}
\hline$S_{f}$ & $A_{s}$ & $N_{I}$ & $N_{t}$ & $S_{f}$ & $A_{s}$ \\
\hline$N_{I}$ & $A_{s}$ & $N_{I}$ & $N_{t}$ & $S_{f}$ & $N_{t}$ \\
\hline$A_{s}$ & $N_{I}$ & $N_{t}$ & $S_{f}$ & $A_{s}$ & $N_{I}$ \\
\hline$S_{f}$ & $A_{s}$ & $S_{f}$ & $A_{s}$ & $N_{I}$ & $A_{s}$ \\
\hline$N_{t}$ & $S_{f}$ & $A_{s}$ & $N_{I}$ & $A_{s}$ & $A_{s}$ \\
\hline$N_{I}$ & $S_{f}$ & $N_{t}$ & $N_{I}$ & $A_{s}$ & $S_{f}$ \\
\hline
\end{tabular}

COMBINATION OF SIX SPECIES

\begin{tabular}{|l|l|l|l|l|l|}
\hline$N_{t}$ & $L_{d}$ & $N_{I}$ & $A_{s}$ & $A_{a}$ & $S_{f}$ \\
\hline$N_{I}$ & $A_{a}$ & $N_{I}$ & $S_{f}$ & $L_{d}$ & $A_{s}$ \\
\hline$N_{I}$ & $N_{t}$ & $L_{d}$ & $S_{f}$ & $A_{s}$ & $L_{d}$ \\
\hline$L_{d}$ & $S_{f}$ & $N_{t}$ & $L_{d}$ & $A_{s}$ & $S_{f}$ \\
\hline$S_{f}$ & $N_{I}$ & $A_{s}$ & $A_{a}$ & $N_{l}$ & $N_{I}$ \\
\hline$A_{s}$ & $S_{f}$ & $A_{a}$ & $N_{t}$ & $S_{f}$ & $A_{a}$ \\
\hline
\end{tabular}

Figure 3 Experimental plots showing the combination of the 2, 4 or 6 plant species. Individual plants were separated $0.25 \mathrm{~m}$ one from another in horizontal and vertical rows. The drawing is not made to

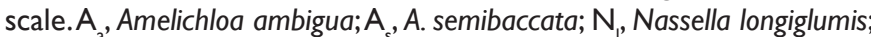
$\mathrm{N}, \mathrm{N}$. tenuis; $\mathrm{L}_{\mathrm{d}}$, Larrea divaricata; $\mathrm{S}_{\mathrm{f}}$ Schinus fasciculatus.

\section{Results}

Identity and plant species richness in experimental plots on soil microbial respiration at different stages of developmental morphology

There was no effect neither of year or species $(p>0.05)$. The interaction between species richness and plant developmental morphology stage was significant $(\mathrm{p}<0.05)$. Basal respiration was greater $(p<0.05)$ at the reproductive than vegetative stage of developmental morphology on monocultures and mixtures of 6 species (Figure 4). At the reproductive stage of developmental morphology, basal respiration was greater $(\mathrm{p}<0.05)$ at greater (combination of 6 species) than lower (monocultures) species richness (Figure 4).

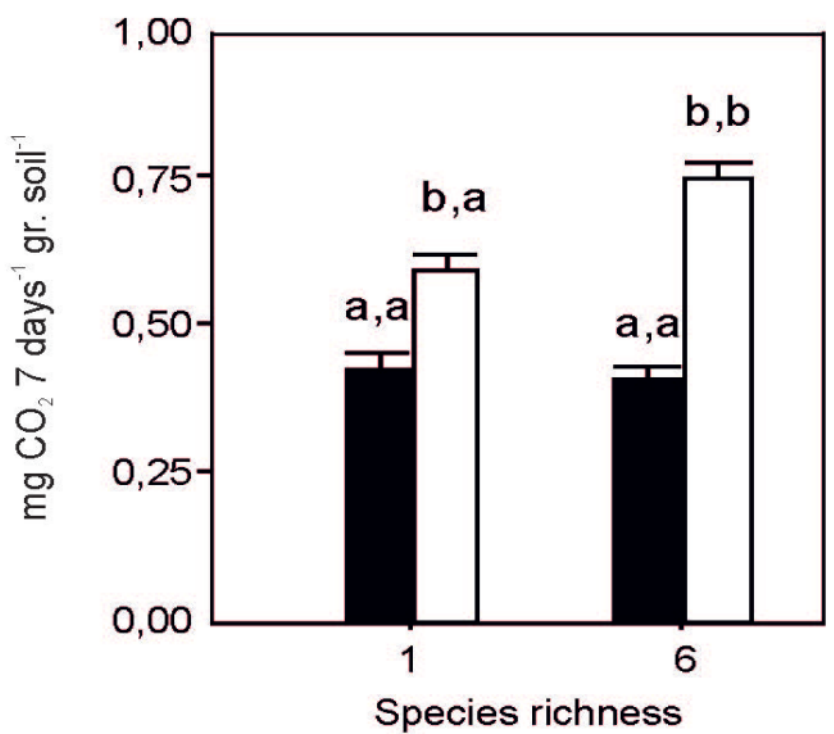

Vegetative

Reproductiv

Figure $4 \mathrm{CO}_{2}$ production ( $\mathrm{mg} /$ week/gr soil) at different stages of developmental morphology (vegetative and reproductive) and species richness (monoculture and mixture of 6 species). Each histogram is the mean +1 standard error of $n=72$. Different letters on histograms indicate significant differences $(p \leq 0.05)$ between the different stages of developmental morphology within the same species richness (first letter) or between different species richness (I versus 6 species mixture) within the same stage of developmental morphology.

Except on L. divaricata in 2014, soil basal respiration in both study years was greater $(p<0.05)$ at the reproductive than vegetative stage of developmental morphology in all study species (Figure 5). Basal respiration increased $(\mathrm{p}<0.05)$ in L. divaricata, $N$. longiglumis and $S$. fasciculatus as species richness also increased (Figure 6). There was no effect $(\mathrm{p}>0.05)$ of species richness on soil basal respiration in the other species (Figure 6).

\section{Discussion}

The magnitude of the soil microorganism activity varies too much during short-time periods of hours to days and months. ${ }^{46}$ At least in part, this is because of predation of soil microorganisms by animals, and abiotic stresses such as cycles of wet and dry years. ${ }^{46}$ The relationships between plants and soil biological communities 
work to a seasonal scale, involving several mechanisms that are important for nutrient supply to plants during the growing season. Schadt et al ${ }^{47}$ reported that seasonal changes on microbial biomass were associated with changes in the composition of the microbial communities. Fungi dominated during winter utilizing complex plant residues, while bacteria associated to root exudates were the most active during summer. ${ }^{48}$ There is also an almost complete change in the microbial community between winter and summer Wilhelm et al. ${ }^{49}$ These seasonal dynamics in the microbial communities are important because they control the temporal nutrient partitioning between plants and soil microorganisms throughout the growing seasons. ${ }^{45}$ The greater respiratory activity found in fall at the Monte might be due to aging of the shrub plants, which might give a weak carbon pulse that could foster microbial growth. ${ }^{50}$ The chemical variation of these compounds provides a potential nutrient source that could promote diversity in the microbial community. ${ }^{51}$ For example, microbial biomass in general, and that of fungi in particular, is improved if litter is rich in phenolic compounds of low molecular weight. ${ }^{52}$ However, if litter is rich in carbohydrates and sugars, bacterial growth is increased. ${ }^{53}$ While microbial biomass increases, plant litter carbon and nitrogen are consumed and mineralized. ${ }^{54}$ Phenolic compounds that foster predominance of fungi species are less easily degradable. ${ }^{47}$

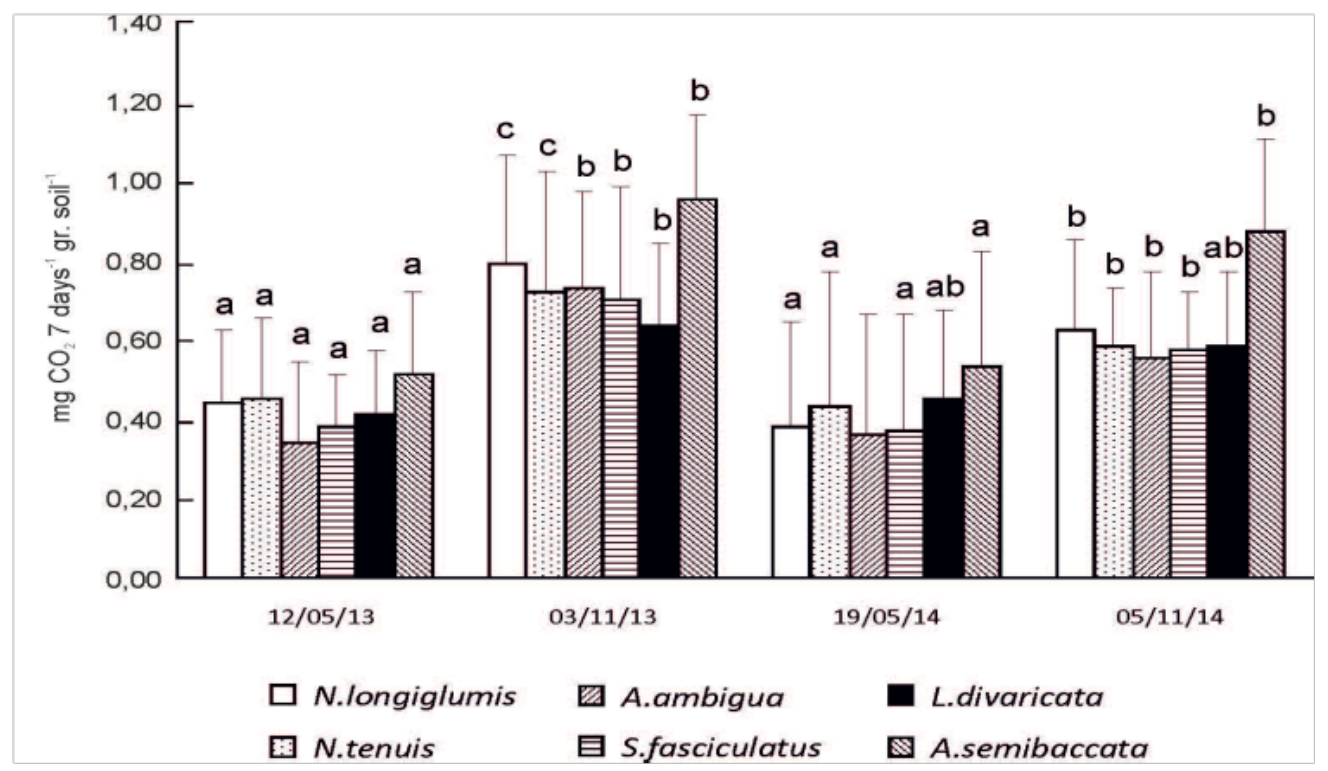

Figure 5 Basal soil respiration ( $\mathrm{mg} \mathrm{CO} .7$ días $\left.^{-1} \cdot \mathrm{g}^{-1}\right)$ underneath 6 plant species during the period 20I3/20I4. Each histogram is the mean of $\mathrm{n}=12$ (A. ambigua and L. divaricata), $\mathrm{n}=18$ (N. clarazzii and S. fasciculatus), and $\mathrm{n}=24$ ( N. tenuis and A. semibaccata) +1 standard error. Different letters indicate significant differences $(p \leq 0.05)$ throughout the sampling dates within each species.

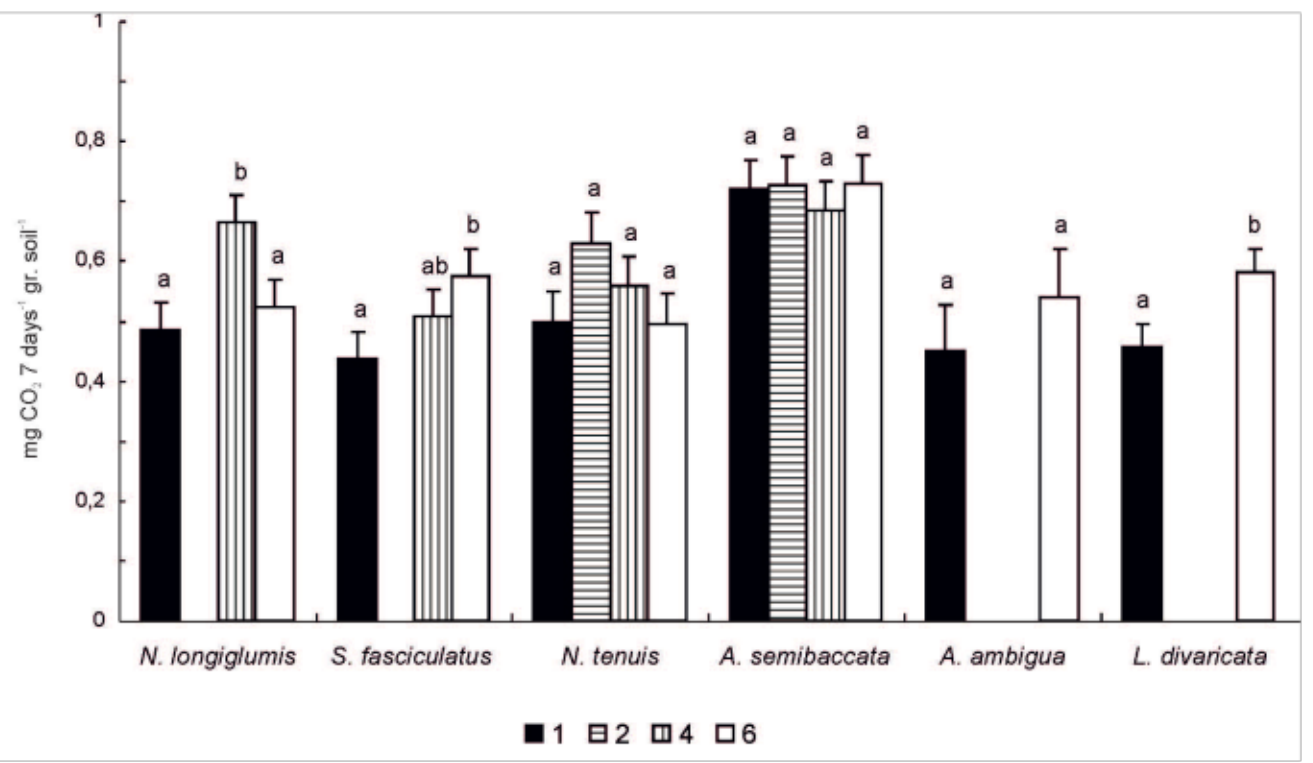

Figure 6 Soil basal respiration as a function of species richness within each species. Each histogram is the mean of $n=24+\mid$ standard error. Different letters indicate significant differences $(p \leq 0.05)$ among different species richness within each species. 
In November, the lower respiratory activity under field conditions agrees with that reported by other authors. ${ }^{55}$ During spring and summer, Sicardi et al. ${ }^{55}$ detected a lower soil microbial population up to $10 \mathrm{~cm}$ soil depth. This could be due to the high soil temperatures and lower soil moisture at this depth. The respiratory activity of the microorganisms can be inhibited by the high conductivity. This suggests that measurements, such as the $\mathrm{CO}_{2}$ release, reflect the existent tension in saline soils of arid regions. In the experimental plots there was a cyclic behavior of respiration during the two study years. There was a lower soil basal respiration in May 2013/2014, when the species were actively growing at the vegetative stage of morphological development, than in November, when grasses and shrubs were at the flowering and fructification developmental stages. These seasonal dynamics in the microbial communities are important because they control the temporal nutrient partitioning between the plants and the soil microorganisms throughout the yearly seasons. ${ }^{3}$ Soil respiration can exhibit seasonal and daily variations. ${ }^{56}$ Chang et al. ${ }^{57}$ suggested that soil temperature represents most of the seasonal variation in basal soil respiration. The efflux of carbon dioxide from the soil is a combination of two factors: (I) respiration from the rhizosfere, including root respiration and respiration coming from the metabolism of the rhizosphere deposits, and (II) microbial decomposition of soil organic matter. ${ }^{58}$ Substrates for respiration of the rhizosfere came from the $\mathrm{C}$ recently fixed by photosynthesis, while decomposition of soil organic matter is mostly the result of the soil heterotrophic activities utilizing its own carbon. Both processes occur at the same time, and they are also tied up with the interactions of the rhizosphere. ${ }^{58}$

Plant developmental morphology on annual and perennial species of the genus Bromus greatly affected assimilate partitioning aboveand belowground..$^{59}$ The percentage of carbon lost by respiration was always greater during the reproductive stages. ${ }^{59}$ Several authors have attempted to give a general estimate of how carbon is used by the rhizosphere of the different plant species under different conditions. ${ }^{60}$ There was a decline in tillering at the reproductive stage of developmental morphology, and this decline was correlated with the appearance of reproductive structures in B. erectus. ${ }^{59}$ During the reproductive stages of developmental morphology, respiration might partly be due to either a greater root translocation rate because of the formation of the new reproductive structures or a greater exudation of compounds by roots. ${ }^{61}$ This agreed with a concomitant increase in the proportion of carbon translocated from the soil. ${ }^{59}$

Basal soil respiration was generally either greater or similar, but not lowers, as the number of species increased in the experimental plots. It is known that particular species can modify the size and the activity of the soil microbial populations. When this is the case, these species have the potential of affecting key ecosystem processes such as soil respiration. ${ }^{17}$ Herbaceous communities in particular (Leontodon hispidus, Succisa pratensis, Campanula rotundifolia and Viola riviniana) were associated with greater soil respiration rates, independently of species richness. ${ }^{17}$ However, the relative importance of plant diversity and community composition in regulating soil respiration rates is still unknown. ${ }^{17}$

Various studies have demonstrated that increases in plant species richness can increase organic matter decomposition throughout changes in nutrient availability. ${ }^{62}$ Increases in nitrogen mineralization relate with a greater nitrogen availability for the decomposing community. This might contribute to explain the accelerated $\mathrm{CO}_{2}$ production induced by root residues coming from soils having greater plant species richness. Nitrogen is a limiting nutrient in Monte ecosystems..$^{63}$ In our study without legumes, nitrogen was most likely an important factor in limiting growth of the study species. This is similar to that reported by van Ruijven \& Berendse. ${ }^{64}$ A greater nitrogen availability can stimulate the soil microbial activity to decompose root litter with a high $\mathrm{C} / \mathrm{N}$ ratio. This is true as long as the root litter contains easily decomposable carbon compounds. ${ }^{65}$ A greater plant species richness can potentially increase the soil respiration rates after litter addition, which will improve soil quality. ${ }^{24}$ Studies that have used mixtures of leaf litter, however, have not reported additive effects of such mixtures for increasing soil respiration. ${ }^{66}$

The mixture of above- and belowground litter of various species can either accelerate or inhibit its decomposition in comparison to that expected from litter coming from only one species ${ }^{67}$ This phenomenon is often observed when the mixture components vary in resource quality. ${ }^{68}$ It also suggests that the litter coming from different plant functional groups might cause a non-additive effect. For example, nitrogen released from the decomposition of nitrogen-rich litter might facilitate the decomposition of nitrogen-poor litter. ${ }^{66}$ Ithurrart et al. ${ }^{31}$ demonstrated that soil below the canopy of $A$. ambigua plants had a greater concentration of available nitrogen than that below the canopy of $N$. tenuis. This result could be associated with a greater contribution of organic matter from the roots of A. ambigua than from those of $N$. tenuis. Saint Pierre et al. ${ }^{69}$ reported a greater root lenght density (cm root/ ${ }^{3}$ ) on plants of A. ambigua than on those of $N$. tenuis towards the end of spring at the same study site than ours. Ambrosino et al. ${ }^{70}$ also reported that roots from plants of $A$. ambigua contributed a greater amount of organic matter to the soil than those of P. ligularis and $N$. tenuis at the same site of study than ours.

Litter components can contain inhibitors (e.g., polyphenols) of microbial growth and the activity of the whole plant community, hindering decomposition of the whole mixture. ${ }^{71}$ Schinus fasciculatus, pertaining to the family of the Anacardiaceae, have toxic phenols that constitute a chemical defense against the attack of insects and vertebrates. ${ }^{72}$ In addition, these compounds can restrict growth of pathogen fungi. ${ }^{73}$ The phenolic compounds coming from lignin decomposition play an important role in almost all biotic and abbiotic interactions that a plant establish with its environment. ${ }^{74}$

Loreau \& Hector $^{75}$ demonstrated that the long-term persistence of the positive relationship between plant diversity and productivity is mostly due to the effects of complementation. The communities with greater species richness exploit more completely the natural resources. ${ }^{76}$ It is likely that the positive relationship between species richness and soil respiration ${ }^{77}$ is due to an increase of the aboveand belowground biomasses promoted by the complementation effects. In studies conducted using experimental plots, Cong et al. ${ }^{78}$ demonstrated that the decomposition of organic matter induced by the addition of root litter was promoted by the increase in species richness. Carbon losses because of greater respiration rates in the more diverse plots might be explained, at least partially, because of a small increase in soil carbon sequestration (18\%) in relation with the greater income of carbon to the soil $(60 \%)$. This latter increment of soil carbon was because of an increased belowground biomass in those plots with greater species richness. Gill \& Jackson ${ }^{79}$ emphasized the lack of information in relation to the effects of litter mixtures on the decomposition of root litter, despite it represents the major income of organic matter in grassland systems. 
Species identity play an important role in the soil by defining the activity of the soil microbial community in arid ecosystems. ${ }^{80}$ In general, vegetation patches of different species in arid systems mitigate the effects of extreme conditions on plants and its associated microbial community, which acts as a soil biodiversity reservoir. ${ }^{81}$ Traditionally, studies of these subjects - ecological causes and consequences of biological diversity - have had an approach on the soil. ${ }^{82}$ This great interest in the soil biological diversity is mostly due to the recognition that the soil microorganisms regulate important ecosystemic processes, like organic matter decomposition and nutrient mineralization..$^{51}$ Besides, because of the probability of the above- and belowground feedback, microbial communities have a key role in ecosystem functioning. ${ }^{83}$

\section{Acknowledgements}

We thank financial support by the National Council for Scientific and Technological Research of Argentina (CONICET) to C.A.B. through grant number 11220130100165.

\section{Conflict of interest}

There is no conflict of interest to declare regarding the publication of this paper.

\section{References}

1. Baldock J, Nelson P. Soil Organic Matter. In: Sumner ME, editor Handbook of Soil Science, CRC Press, Boca Ratón; 2000. p. B25-84.

2. Rashid MI, Mujawar LH, Shahzad T, et al. (2016) Bacteria and fungi can contribute to nutrients bioavailability and aggregate formation in degraded soils. Microbiol Res. 183:26-41.

3. Bardgett RD. The Biology of Soil: A Community and Ecosystem Approach. Oxford Univ. Press, Oxford; 2005.

4. Bardgett RD, Mommer L, De Vries FT. Going underground root traits as drivers of ecosystem processes. Trends Ecol Evol. 2014;29(12):692-699.

5. A'Bear AD, Johnson S, Jones H. Putting the 'upstairs-downstairs' into ecosystem service: what can aboveground-belowground ecology tell us? Biol Contro. 2014;75:97-107.

6. Brewer R. The Science of Ecology. Saunders College Publishing, Orlando; 1994: 118-165, $791 \mathrm{p}$.

7. Dreyer J, Gratton A. Habitat linkages in conservation biological control: lessons from the land-water interface. Biol Control. 2014;75:68-76.

8. Wardle DA, Bardgett RD, Klironomos JN, et al. Ecological linkages between aboveground and belowground biota. Science. 2004;304(5677):1629-1633.

9. Wardle DA, Bonner KI, Barke GM, et al. Plant removals in perennial grassland: vegetation dynamics, decomposers, soil biodiversity, and ecosystem properties. Ecol Monogr. 1999;69(4):535-568

10. Loranger-Merciri G, Barthes L, Gastine A, et al. Rapid effects of plant species diversity and identity on soil microbial communities in experimental grassland ecosystems. Soil Biol Biochem. 2006;38(8):2336-2343.

11. Wang R, Zhang H, Sun L, et al. Microbial community composition is related to soil biological and chemical properties and bacterial wilt outbreak. Sci Rep. 2017;7(1):343

12. Dias ATC, Van Ruijven J, Berends F. Plant species richness regulates soil respiration through changes in productivity. Oecologia. 2010;163(3):805-813.
13. De Boeck HJ, Lemmens CMHM, Vicca S. How do climate warming and species richness affect $\mathrm{CO} 2$ fluxes in experimental grasslands? New Phytol. 2007;175(3):512-522.

14. Raich JW, Tufekcioglu A. Vegetation and soil respiration: correlations and controls. Biogeochemistry. 2000;48(1):71-90.

15. Spehn EM, Hector A, Joshi J, et al. Ecosystem effects of biodiversity manipulations in European grasslands. Ecol Monogr. 2005;75(1):3763.

16. Fargione J, Tilman D, Dybzinski R, et al. From selection to complementarity: shifts in the causes of biodiversity-productivity relationships in a long-term biodiversity experiment. Proc Royal Soc London Biol Sci. 2007;274(1611):871-876.

17. Johnson D, Phoenix GK, Grime JP. Plant community composition, not diversity, regulates soil respiration in grasslands. Biol Lett. 2008;4(4):345-348.

18. Alvarez R, Santanatoglia O. Actividad biológica y biomasa microbiana en diferentes suelos incubados bajo las mismas condiciones ambientales. Ciencia del Suelo. 1985;3(1-2):180-184.

19. Fernández OA, Busso CA. Arid and Semi-Arid Rangelands: Two Thirds of Argentina. RALA Report. 1999;200:41-60.

20. Spehn EM, Joshi J, Schmid B, et al. Aboveground resource use increases with plant species richness in experimental grassland ecosystems. Functional Ecology. 2000;14(3):326-337.

21. Nune JS, Araújo ASF, Nunes LAPL, et al. Land degradation on soil microbial biomass and activity in Northeast Brazil. Pedosphere. 2012;22(1):88-95.

22. Loreau M, Naeem S, Inchausti P, et al. Biodiversity and cosystem functioning: current knowledge and future challenges. Science. 2001;294(5543):804-808.

23. Pankhurst CE, Ophel-Keller K, Doube BM, et al. Biodiversity of soil microbial communities in agricultural systems. Biodivers. Conserv. 1996;5(2):197-209.

24. Wardle DA, Lavelle P. Linkages between soil biota, plant litter quality and decomposition. In: Cadish G, Giller KE, editors. Driven by Nature: Plant Litter Quality and Decomposition. CAB International, Wallingford; 1997. p. 107-124.

25. Hooper DU, Bignell DE, Brown VK, et al. Interactions between aboveground and belowground biodiversity in terrestrial ecosystems: patterns, mechanisms, and feedbacks. Bio Science. 2000;50(12):1049-1061.

26. Schlesinger WH, Andrew JA. Soil respiration and the global carbon cycle. Biogeochemistry. 2000;48(1):7-20.

27. Kuzyakov Y, Gavrichkova O. Time lag between photosynthesis and carbon dioxide efflux from soil: a review of mechanisms and controls. Glob Chang Biol. 2010;16(12):3386-3406.

28. Inoue $\mathrm{T}$, Nagai $\mathrm{S}$, Inoue $\mathrm{S}$, et al. Seasonal variability of soil respiration in multiple ecosystems under the same physical-geographical environmental conditions in central Japan. Forest Sci Technol. 2012;8(2):52-60.

29. Du E, Fang J. Linking belowground and aboveground phenology in two boreal forests in Northeast China. Oecologia. 2014;176(3):883-892.

30. Cabrera AL. Regiones fitogeográficas Argentinas. In: Cabrera AL, editor. Enciclopedia Argentina de Agricultura y Jardinería. Acme SACI Buenos Aires; 1976. 85 p.

31. Ithurrart L, Busso CA, Montenegro $\mathrm{O}$, et al. Total soil available nitrogen under perennial grasses after burning and defoliation. Russ $J$ Ecol. 2017;48(2):122-133. 
32. INTA-CIRN. Mapa de suelos de la provincia de Buenos Aires. Instituto Nacional de Tecnología Agropecuaria. Centro de Investigación de Recursos Naturales. Instituto de Evaluación de Tierras, Buenos Aires, Argentina; 1989.

33. Giorgetti $\mathrm{H}$, Montenegro $\mathrm{O}$, Rodríguez $\mathrm{G}$, et al. The comparative influence of past management and rainfall on range herbaceous standing crop in east-central Argentina: 14 years of observations. $J$ Arid Environ. 1997;36(4):623-637.

34. Distel RA, Bóo RM. Vegetation states and transitions in temperate semiarid rangelands of Argentina. In: West NE, editor. Rangelands in a Sustainable Biosphere. Proceedings of the Fifth International Rangeland Congress, Society for Range Management, Denver; 1996. p. 117-118.

35. Saint Pierre C, Busso CA, Montenegro O, et al. Root proliferation in perennial grasses of low and high palatability. Plant Ecol. 2002;165(2):161-169.

36. Bóo RM, Peláez DV. Ordenamiento y clasificación de la vegetación en un área del sur del Distrito del Caldén. Bol Soc Arg Bot. 1991;27:135-141.

37. Cano E. Pastizales naturales de La Pampa. Descripción de las especies más importantes, Convenio AACREA - Provincia de La Pampa, Buenos Aires; 1988.

38. Busso CA, Fernández OA. Arid and Semiarid Rangelands of Argentina. In: Gaur MK, Squires VR, editors. Climate Variability Impacts on Land Use and Livelihoods in Drylands. New York, Springer; 2018. p. 261-291.

39. Rúgolo de Agrasar ZE, Steibel PE, Troiani HO. Manual ilustrado de las gramíneas de la Provincia de La Pampa. Univ. Nacional de La Pampa, Univ. Nacional de Río Cuarto, Río Cuarto; 2005.

40. Passera CB, Cavagnaro JB, Sartor CE. Plantas C3, C4 y CAM nativas del Monte árido argentino, adaptaciones y potencial biológico. $\mathrm{C} 4 \mathrm{y}$ CAM Características Generales y uso en programas de desarrollo de tierras áridas y semiáridas. Homenaje al Dr. J. Lopez Gorgé. Consejo Superior de Investigaciones Científicas; 2010. p. 165-176.

41. Torres YA, Busso CA, Montenegro O, et al. Plant growth and survival of five perennial grass genotypes exposed to various defoliation managements in arid Argentina. Grass Forage Sci. 2013;69(4):580-595.

42. Torres YA, Busso CA, Montenegro O, et al. Root proliferation in perennial grasses in arid Patagonia, Argentina. $J$ Arid Land. 2014;6(2):195-204.

43. Distel RA, Fernández OA. Productivity of Stipa tenuis Phil. and Piptochaetium napostaense (Speg.) Hack in semi-arid Argentina. J Arid Environ. 1986;11:93-96.

44. Zibilski LM. Carbon mineralization. In: Weaver RW, Angle S, editors Methods of soil analysis. part 2, Microbiological and Biochemical Properties. Soil Science Society of America, Madison; 1994. p. 835863.

45. Dunnett CW. A multiple comparison procedure for comparing several treatments with a control. Journal of the American Statistical Association. 1955;50:1096-1121.

46. Bardgett RD. The Biology of Soil: A Community and Ecosystem Approach. Oxford Univ. Press, Oxford; 2005.

47. Schadt CW, Martin AP, Lipson DA, et al. Seasonal dynamics of previously unknown fungal lineages in tundra soils. Science. 2003;301(5638):1359-1361.
48. Lipson DA, Schmidt SK. Seasonal changes in an alpine bacterial community in the Colorado Rocky Mountains. Appl Environ Microbiol. 2004;70(5):2867-2879.

49. Wilhelm SW, Wilhelm GR, LeCleir GR, et al. Seasonal changes in microbial community structure and activity imply winter production is linked to summer hypoxia in a large lake. FEMS Microbiol Ecol. 2014;87(2):475-485.

50. Catalán N, Kellerman AM, Peter H, et al. Absence of a priming effect on dissolved organic carbon degradation in lake water. Limnol and Oceanogr. 2015;60(1):159-168.

51. Van Der Heijden MGA, Bardgett RD, Van Straalen NM. The unseen majority: soil microbes as drivers of plant diversity and productivity in terrestrial ecosystems. Ecol Lett. 2008;11(3):296-310.

52. Kuiters AT. Role of phenolic substances from decomposing forest litter in plant-soil interactions. Acta Bot Neerl. 1990;39(4):329-348.

53. Bowman WD, Steltzer H. Positive feedbacks to anthropogenic nitrogen deposition in Rocky Mountain alpine tundra. Ambio. 1998;27(7):514 517.

54. Schimel JP, Bennett J. Nitrogen mineralization: challenges of a changing paradigm. Ecology. 2004;85(3):591-602.

55. Sicardi M, Garcia-Préchac F, Frioni L. Soil microbial indicators sensitive to land use conversion from pastures to commercial Eucalyptus grandis (Hill ex Maiden) plantations in Uruguay. Appl Soil Ecol. 2004;27(2):125-133.

56. Wang C, Yang J, Zhang Q. Soil respiration in six temperate forests in China. Global Change Biology. 2006;12(11):2103-2114.

57. Chang SX, Shi Z, Thomas BR. Soil respiration and its temperature sensitivity in agricultural and afforested poplar plantation systems in northern Alberta. Biol Fertil Soils. 2016;52(5):629-641.

58. Cheng W, Kuzyakov Y. Root effects on soil organic matter decomposition. In: Wright S, Zobel R, editors. Roots and Soil Management: Interactions Between Roots and the Soil. Agronomy Monograph No. 48, American Society of Agronomy, Wisconsin; 2005. p. 119-143.

59. Warembourg FR, Estelrich HD. Plant phenology and soil fertility effects on below-ground carbon allocation for an annual (Bromus madritensis) and a perennial (Bromus erectus) grass species. Soil Biol Biochem. 2001;33(10):1291-1303.

60. Rattray EAS, Paterson E, Killham K. Characterisation of the dynamics of C-partitioning within Lolium perenne and to the rhizosphere microbial biomass using 14C pulse chase. Biol Fertil Soils. 1995;19(4):280-286.

61. Swinnen J, Van Veen JA, Merckx R. 14C pulse-labelling of field-grown spring wheat: an evaluation of its use in rhizosphere carbon budget estimations. Soil Biol Biochem. 1994;26(2):161-170.

62. Hooper DU, Chapin FS, Ewel JJ, et al. Effects of biodiversity on ecosystem functioning: a consensus of current knowledge. Ecol Monogr. 2005;75(1):3-35.

63. Villagra PE. Aspectos ecológicos de los algarrobales argentinos. Multequina. 2000;9(2):35-51.

64. Ruijven JV, Berendse F. Diversity-productivity relationships: initial effects, long-term patterns, and underlying mechanisms. Proc Nat Acad Sci. 2005;102(3):695-700.

65. Cong WF, van Ruijven J, van der Wer W, et al. Plant species richness leaves a legacy of enhanced root litter-induced decomposition in soil. Soil Biol Biochem. 2015;80:341-348. 
66. Handa IT, Aerts R, Berendse F, et al. Consequences of biodiversity loss for litter decomposition across biomes. Nature. 2014;509:218-221.

67. Hättenschwiler S, Tiunov AV, Scheu S. Biodiversity and litter decomposition in terrestrial ecosystems. Ann Rev Ecol Evol Syst. 2005;36:191-218

68. Wardle DA, Bonner KI, Nicholson KS. Biodiversity and plant litter: experimental evidence which does not support the view that enhanced species richness improves ecosystem function. Oikos. 1997;79(2):247-258

69. Saint Pierre C, Busso CA, Montenegro O, et al. Direct assessment of competitive ability and defoliation tolerance in perennial grasses. Can J Plant Sci. 2004;84(1):195-204

70. Ambrosino M, Busso C, Cardillo D, et al. Biomasa de raíces de Poa ligularis, Nassella tenuis y Amelichloa ambigua expuestas a defoliación. XXVI Reunión Argentina de Ecología, 1 al 3 Noviembre; 2014. $178 \mathrm{p}$

71. Schimel J, Cates R, Ruess R. The role of balsam poplar secondary chemicals in controlling soil nutrient dynamics through succession in the Alaskan taiga. Biogeochemistry. 1998;42(1-2):221-234.

72. Mitchell JD. The poisonous Anacardiaceae genera of the world Advances in Economic Botany. 1990;8:103-129.

73. Cojocaru M, Droby S, Glotter E, et al. 5-(12-Heptadecenyl)-resorcinol, the major component of the antifungal activity in the peel of mango fruit. Phytochemistry. 1986;25(5):1093-1095

74. Waterman P, Mole S. Analysis of Phenolic Plant Metabolites. Blackwell Scientific Publication, Oxford; 1994
75. Loreau M, Hector A. Partitioning selection and complementarity in biodiversity experiments. Nature. 2001;412:72-76.

76. Van Ruijven J, Berendse F. Positive effects of plant species diversity on productivity in the abscence of legumes. Ecol Lett. 2003;6(3):170-175.

77. Zak RA, Holmes WE, White DC, et al. Plant diversity, soil microbial communities, and ecosystem function: are there any links? Ecology. 2003;84(8):2042-2050.

78. Cong WF, Van Ruijven J, Mommer L, et al. Plant species richness promotes soil carbon and nitrogen stocks in grasslands without legumes. J Ecol. 2014;102(5):1163-1170.

79. Gill RA, Jackson RB. Global patterns of root turnover for terrestrial ecosystems. New Phytol. 2000;147(1):13-31.

80. Hortal S, Bastida F, Moreno JL, et al. Benefactor and allelopathic shrub species have different effects on the soil microbial community along an environmental severity gradient. Soil Biol Bioch. 2015;88:8-57.

81. Busso CA, Bonvissuto G, Torres YA. Germination and seedling establishment of grasses and shrubs in arid Patagonia, Argentina. Land Degradation and Development. 2012;23:116-129.

82. Mittelbach GG, Steiner CF, Scheiner SM, et al. What is the observed relationship between species richness and productivity? Ecology. 2001;82(9):2381-2396.

83. Wardle DA. Communities and Ecosystems: Linking the Aboveground and Belowground Components. Monographs in Population Biology 34. Princeton University Press, New Jersey; 2002 